\title{
Abundance and characterization of microorganisms isolated from oil palm empty fruit bunches waste under aerobic, anaerobic, and facultative anaerobic conditions
}

\author{
DERMIYATI ${ }^{1, \vartheta}$, RADIX SUHARJO ${ }^{2}$, MARELI TELAUMBANUA ${ }^{3}$, RULLY YOSITA $^{4}$, \\ ANGGI WINANDA SARI ${ }^{5}$, ANIS PUJI ANDAYANI ${ }^{5}$ \\ ${ }^{1}$ Department of Soil Science, Faculty of Agriculture, Universitas Lampung. Jl. Prof. Sumantri Brojonegoro, Bandar Lampung 35145, Lampung, \\ Indonesia. Tel.: + 62-721-701609, Fax .: +62-721-702767, ^email: dermiyati.1963@fp.unila.ac.id \\ ${ }^{2}$ Department of Plant Protection, Faculty of Agriculture, Universitas Lampung. Jl. Prof. Sumantri Brojonegoro, Bandar Lampung 35145, Lampung, \\ Indonesia \\ ${ }^{3}$ Department of Agricultural Engineering, Faculty of Agriculture, Universitas Lampung. Jl. Prof. Sumantri Brojonegoro, Bandar Lampung 35145, \\ Lampung, Indonesia \\ ${ }^{4}$ Agronomy Graduate Program, Universitas Lampung. Jl. Prof. Sumantri Brojonegoro, Bandar Lampung 35145, Lampung, Indonesia \\ ${ }^{5}$ Department of Agrotechnology, Faculty of Agriculture, Universitas Lampung. Jl. Prof. Sumantri Brojonegoro, Bandar Lampung 35145, Lampung, \\ Indonesia
}

Manuscript received: 16 July 2020. Revision accepted: 21 August 2020.

\begin{abstract}
Dermiyati, Suharjo R, Telaumbanua M, Yosita R, Sari AW, Andayani AP. 2020. Abundance and characterization of microorganisms isolated from oil palm empty fruit bunches waste under aerobic, anaerobic, and facultative anaerobic conditions. Biodiversitas 21: 4213-4220. Increased production of palm oil causes an increase in oil palm empty fruit bunches waste, while the utilization of the waste has not been carried out optimally. Oil palm empty fruit bunches contain high cellulose content which promotes the development of various types of bacteria with different characteristics. This study was aimed to determine the abundance and the characterization of bacteria that were isolated from extract suspension of oil palm empty fruit bunches in the form of a local microorganism solution under aerobic, anaerobic, and facultative anaerobic conditions. For isolation, the oil palm empty fruit extract suspension was inoculated on media Plate Count Agar Peptone and bacterial abundance was determined. Various bacterial characterization test included bacterial morphology test in the form of color and shape of macroscopic isolates, gram test using KOH $3 \%$, fermentative oxidative test, soft rot test on potato tubers, hypersensitivity test on tobacco plant leaves, and hypo virulent test which was indicated by the presence of symptoms of disease in cucumber sprouts and indicated in the disease severity index (DSI) was carried out. The results of local microorganism solution isolation from oil palm empty fruit bunches obtained as many as 220 bacterial isolates consisting of 84 isolates in aerobic condition, 68 isolates in anaerobic condition, and 68 isolates in facultative anaerobic condition. The

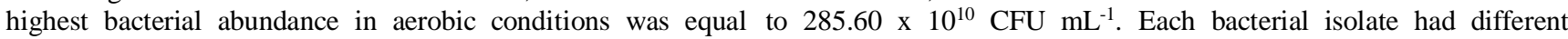
characteristics. Most of the characteristics of bacteria were turbid white (34.55\%), round (69.55\%), gram-positive (76.36\%), fermentative $(89.55 \%)$, softrot negative $(71.82 \%)$, hypersensitive negative $(97.27 \%)$, and virulent $(74.55 \%)$.
\end{abstract}

Keywords: Abundance, bacteria, characteristics, local microorganisms

\section{INTRODUCTION}

Oil palm empty fruit bunches (EFB) is a kind of biomass waste formed during the production process of palm oil (Rahayu et al. 2019). Nowadays, the availability of oil palm empty fruit bunches as waste is increasingly abundant in line with the increased oil palm production and land area. According to USDA (2019), with further expansion in mature areas, palm oil production in Indonesia was forecast to reach 43 million tons in 2019/20, a 1.5 million ton increased from 2018/19. Moreover, as stated by Mariska (2019) that Indonesia's crude palm oil production was 34.7 million metric tons in August 2019, it rose by $14 \%$ compared to August 2018. Furthermore, Indonesia planting target in 2019 was 200,000 ha, however, the implementation was only about 20,000 ha and by 2022 the planting target is 700,000 ha. The increasing planting area would increase palm oil production as well as their wastes. Furthermore, Santi et al. (2019) reported that until now the potential availability of oil palm empty fruit bunches as waste can reach 47 million tons per year, but so the utilization of the waste has not been carried out optimally.

Oil palm empty fruit bunches can be utilized as compost or an organic fertilizer which is useful to increase palm oil production and to improve physical, chemical, and biological soil properties (Yi et al. 2019). Furthermore, Yi et al. (2019) found that application of either compost or fertilizer alone increased fresh fruit bunch yield, from 23.24 to 25.49 or $25.55 \mathrm{t} \mathrm{ha}^{-1} \mathrm{yr}^{-1}$. Soil chemical properties such as soil $\mathrm{pH}$, organic $\mathrm{C}$, total- $\mathrm{N}$ and $-\mathrm{P}$, available-P, exchangeable cations $\left(\mathrm{K}^{+}, \mathrm{Ca}^{2+}\right.$, and $\left.\mathrm{Mg}^{2+}\right)$ and cation exchange capacity were significantly increased by the application of compost, making compost an effective organic material and nutrient source for improving the health of soils under oil palm cultivation. Other than that, oil palm empty fruit bunches can also be used as biofertilizer because it contains bacteria that can bind 
nitrogen and phosphate solvents (Hoe et al. 2016), as degraders lignin bacteria (Tahir et al. 2019), as organic materials decomposers (Chin et al. 2017), as well as a fuel for power plant (Han and Kim 2018). Oil palm empty fruit bunches also contain abundant bacteria, high cellulose so it can be used as a source of bacterial energy for the biosynthesis process (Md Yunos et al. 2015; Rosli et al. 2017). Moreover, Rosli et al. (2017) found that the oil palm empty fruit bunches contain the polymeric carbohydrates such as cellulose and hemicellulose. Also, the oil palm empty fruit bunches fiber was made up of $31.4 \%$ of glucan, $18.6 \%$ xylan and $2.7 \%$ arabinan with the lignin accounted for around $23.9 \%$.

Various studies have shown that bacterial isolates obtained from oil palm empty fruit bunches either in the fresh form, the weathered form, the compost form, the suspension extract form (local microorganisms solution) varied. The research of Ariana et al. (2017) resulted in the isolation of as many as 430 microbes from oil palm empty fruit bunches. Also, Harith et al. (2014) reported that 24 bacterial isolates were recovered from oil palm industry waste. Besides, Lai et al. (2017) obtained 34 bacterial isolates that were successfully isolated from compost oil palm empty fruit bunches. The abundance of bacteria can also be obtained through extract suspension of oil palm empty fruit bunches in the form of a local microorganism solution. A local microorganism solution is a fermented liquid from plant or animal waste and contain microorganisms with different species in an area due to differences in environmental conditions (Adrizal et al. 2017). Besides, a local microorganism solution contains macro and micronutrient elements and also contains bacteria which potentially as a material overhaul organic, growth stimulant, and as a pest and disease control agent plant. Astriani et al. (2017) isolated 3 kinds of local microorganism solution samples from vegetable waste, then they obtained 79 bacterial isolates with the characteristics of most bacteria that were round, uneven edges, and white colonies.

The diversity of abundance and characterization of bacteria isolated from extract suspension of local microorganisms solution depends on the source of raw material used as well as the conditions during fermentation. So far, the information regarding the fermentation conditions under aerobic, anaerobic, and facultative anaerobic are not available yet. These conditions may affect the growth of bacteria which is related to available oxygen during the fermentation processes. Therefore, this study was aimed to explore the abundance and characterization of indigenous bacteria isolated from the extract suspension based on oil palm empty fruit bunches under a different fermentation process namely aerobic, anaerobic, and facultatively anaerobic.

\section{MATERIALS AND METHODS}

\section{Development of local microorganism solutions from oil palm empty fruit bunches}

Local Microorganism solution was developed using oil palm empty fruit bunches in three conditions, namely aerobic, anaerobic, and facultative anaerobic as described by Dermiyati et al. (2019). Making a suspension of local microorganisms was done by mixing $2.5 \mathrm{~kg}$ of finely chopped oil palm empty fruit bunches, $0.5 \mathrm{~kg}$ brown sugar, $2.5 \mathrm{~L}$ rice washing water, and $2.5 \mathrm{~L}$ coconut water, then put into the reactor machine and each fermentation condition contains the same ingredients. The process of making local microorganism solution was performed using a reactor machine developed by Telaumbanua et al. (2019). Oil palm empty fruit bunches were taken from PT Perkebunan Nusantara (PTPN) VII, Rejosari, Natar, Lampung Province, Indonesia.

\section{Bacterial isolation and propagation}

Bacterial isolation and bacterial propagation were performed as per the method described by Dermiyati et al. (2019).

\section{Bacterial isolation}

All the collected samples were diluted at $10^{-8}, 10^{-10}$, and $10^{-12}$. From each dilution series, $50 \mu \mathrm{L}$ of the suspension were spread into sterile plastic petri dish (diameter $9 \mathrm{~cm}$ ) containing Plate Count Agar Peptone (PCAP) media (plate count agar (PCA; OXOID®; England) $17.4 \mathrm{~g}$, peptone (OXOID $\AA$; England) $2.5 \mathrm{~g}$, agar $2 \mathrm{~g}$, and $1000 \mathrm{~mL}$ distilled water). Observation of the total bacterial colonies which were emerged was performed every day for 7 days.

\section{Bacterial propagation}

The emerging bacteria were purified by placing into a sterile plastic Petri dish (9 $\mathrm{cm}$ in diameter) containing Yeast Peptone Agar (YPA) peptone media (OXOID®, England) $10 \mathrm{~g}$, Yeast Extract (HIMEDIA®; India) $5 \mathrm{~g}$, agar $20 \mathrm{~g}$, and $1000 \mathrm{~mL}$ distilled water). For further analysis, the bacteria were streaked into Potato Peptone Glucose Agar (PPGA) slant media.

\section{Bacterial abundance}

Bacterial abundance was shown by the number of bacterial populations through observing the numbers of bacterial isolates that grew on Plate Count Agar Peptone media for 7 days after isolation such as that explained above.

\section{Bacterial characteristics}

Bacterial characteristics were seen based on bacterial morphology test, Gram's test with $3 \% \mathrm{KOH}$, OxidationFermentation, or the OF test, soft rot test on potato tubers, hypersensitive test, and hypovirulent test.

Bacterial morphology was confirmed by observing the bacterial isolates from color and shape (Linda et al. 2018). The morphological characteristics test of the bacteria was carried out by observing the bacteria that grew on PCAP media for 7 days after spreading.

Gram's test with $\mathrm{KOH} 3 \%$ was performed using the method by Chandra and Mani (2011). The nature of bacteria was divided into two, namely a gram-positive if it did not produce mucus when reacting with $\mathrm{KOH} 3 \%$ and a 
gram-negative which produced mucus when reacting with $\mathrm{KOH} 3 \%$.

Oxidation-fermentation test was performed based on the method described by Cymru and Wales (2010), it used 2 test tubes containing media with one of the tubes was added as much as $1 \mathrm{~mL}$ of paraffin oil after bacterial isolates were inserted into the media and then it was observed for 7 days discoloration on the media. Change the color of the media from green to yellow on both tubes indicated the bacteria was fermentative, while if discoloration occurred in the tube which was given by paraffin oil then the bacteria was oxidative.

Soft rot test was done based on the method by Khlaif and Wreikat (2018) through scratching bacterial isolates in the middle of the potato tuber and the reaction was observed 24 hours. Negative reactions were indicated by not any changes in potato tubers, while positive reactions occurred when it was the decay and soft stabbed in the middle of a potato tuber carved by bacteria.

Hypersensitive test was prepared based on the method by Istiqomah and Kusumawati (2018) by injecting a bacterial isolate suspension into the tissue of the lower surface of the tobacco leaf. Positive response from tobacco plants if there was a necrosis of the leaves which was injected with a bacterial suspension at 24 hours after application.

Hypovirulent test was performed according to the method of Suharjo et al. (2018). The test used a cucumber as an indicator plant and observe the development of the symptoms of the disease in the hypocotyl or other parts of the sprouts for 14 days, then the results were stated as the disease severity index (DSI). If the isolate is not showing disease symptoms or symptoms caused by cucumber sprouts only a little $(\mathrm{DSI}<2.0)$, the isolate is categorized as hypovirulent.

\section{RESULTS AND DISCUSSION}

The results of bacterial isolates were isolated from the extract suspension of oil palm empty fruit bunches with their isolate codes are shown in Table 1. This study obtained as many as 220 bacterial isolates consisting of 84 isolates under fermentation in aerobic conditions, 68 isolates in anaerobic condition, and 68 isolates in facultative anaerobic conditions. The highest bacterial isolates were in the aerobic conditions which were related to the need for oxygen for the growth of the bacteria. Aerobic bacteria are the species of bacteria which require oxygen for their basic survival, growth, and the process of reproduction (Tortora 2019).

The highest bacterial population resulting from the isolation of the extract suspension of oil palm empty fruit bunches was in the aerobic condition of $285.60 \times 10^{10} \mathrm{CFU}$
$\mathrm{mL}^{-1}$, followed by the anaerobic condition of $230.27 \times 10^{10}$ CFU $\mathrm{mL}^{-1}$, and the facultative anaerobic condition of $175.13 \times 10^{10} \mathrm{CFU} \mathrm{mL} \mathrm{mL}^{-1}$ (Figure 1). This is supported by Zainudin et al. (2013) that bacteria contained in the compost of oil palm empty fruit bunches were dominated by bacteria Bacillus sp., Paenibacillus sp., Pseudomonas sp., and Cellulomonas sp, where the bacteria are included in the aerobic bacteria. Also, aerobic conditions will allow bacteria to grow properly with sufficient oxygen.

Some examples of the isolation results from the extract suspension of oil palm empty fruit bunches at three fermentation conditions are shown in Figure 2. Figure 2.A (i, ii, and iii) are the results of isolation of bacteria in the aerobic condition, Figure 2.B (i, ii, and iii) in the anaerobic condition, while Figure 2.C (i, ii, and iii) in the facultative anaerobic condition. The three conditions of fermentation show an abundance of different bacteria.

Examining the characteristics of bacterial isolates from the extract suspension of oil palm empty fruit bunches in the form of color and shape are presented in Table 2. Of the 220 bacterial isolates obtained, there were 13 types of characteristics in aerobic conditions, 14 types in anaerobic conditions, and 11 types in facultative anaerobic conditions. However, the characteristics of bacterial isolates obtained were dominated by round white followed by turbid white, irregular and round white turbid under all conditions of fermentation. Characteristics of bacteria that are white and round in aerobic conditions are $20.23 \%$, anaerobic conditions are $19.12 \%$, and facultative anaerobic conditions are $27.94 \%$.

The color and shape of bacterial isolates from the extract suspension of oil palm empty fruit bunches were dominated by white color and round shape. Some examples of the characteristics of bacterial isolates are shown in Figure 3.

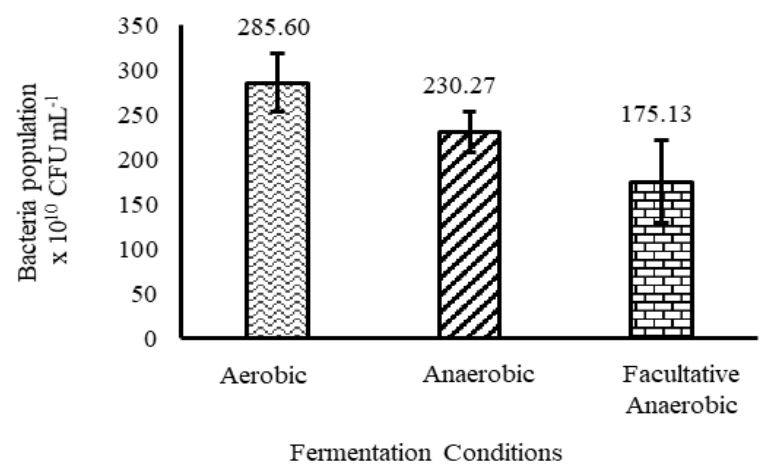

Figure 1. The population of the indigenous bacteria in the extract suspension of oil palm empty fruit bunches 
Table 1. Bacteria isolates from extract suspension of oil palm empty fruit bunches in aerobic, anaerobic, and facultative anaerobic conditions

\begin{tabular}{|c|c|c|c|c|c|c|c|c|c|c|c|}
\hline \multirow{3}{*}{\multicolumn{6}{|c|}{$\begin{array}{l}\text { Table 1. Bacteria isolates from extract suspension of oil palm } \\
\text { empty fruit bunches in aerobic, anaerobic, and facultative } \\
\text { anaerobic conditions }\end{array}$}} & 39 & ASB4 & 39 & ANSPKR10 & 39 & SSP13 \\
\hline & & & & & & 40 & ASB5 & 40 & ANSB7 & 40 & SSPKR16 \\
\hline & & & & & & 41 & ASB6 & 41 & ANSP10 & 41 & SSPKR17 \\
\hline & & & & & & 42 & ASP13 & 42 & ANSB8 & 42 & SSP14 \\
\hline \multirow{3}{*}{\multicolumn{2}{|c|}{$\begin{array}{l}\text { Aerobic } \\
\text { condition }\end{array}$}} & \multirow{3}{*}{\multicolumn{2}{|c|}{$\begin{array}{l}\text { Anaerobic } \\
\text { condition }\end{array}$}} & \multirow{3}{*}{\multicolumn{2}{|c|}{$\begin{array}{l}\text { Facultative } \\
\text { Anaerobic } \\
\text { condition }\end{array}$}} & 43 & ASPKR14 & 43 & ANSP11 & 43 & SSPKR18 \\
\hline & & & & & & 44 & ASPKR15 & 44 & ANSB9 & 44 & SSP15 \\
\hline & & & & & & 45 & ASPKR16 & 45 & ANSPKR11 & 45 & SSP16 \\
\hline No. & Isolate code & No. & Isolate code & No. & Isolate code & 46 & ASK8 & 46 & ANSPKR12 & 46 & SSP17 \\
\hline 1 & ASP1 & 1 & ANSP1 & 1 & SSP1 & 47 & ASB7 & 47 & ANSP12 & 47 & SSK4 \\
\hline 2 & ASP2 & 2 & ANSB1 & 2 & SSP2 & 48 & ASPKR17 & 48 & ANSKP1 & 48 & SSP18 \\
\hline 3 & ASB1 & 3 & ANSB2 & 3 & SSP3 & 49 & ASO1 & 49 & ANSP13 & 49 & SSP19 \\
\hline 4 & ASPKR1 & 4 & ANSB3 & 4 & SSP4 & 50 & ASPKR18 & 50 & ANSPK1 & 50 & SSP20 \\
\hline 5 & ASP3 & 5 & ANSK1 & 5 & SSPKR1 & 51 & ASK9 & 51 & ANSP14 & 51 & SSPKRL1 \\
\hline 6 & ASB2 & 6 & ANSK2 & 6 & SSPKR2 & 52 & ASP14 & 52 & ANSPKRL1 & 52 & SSPKRL2 \\
\hline 7 & ASB3 & 7 & ANSK3 & 7 & SSK1 & 53 & ASB8 & 53 & ANSP15 & 53 & SSPB1 \\
\hline 8 & ASK1 & 8 & ANSM1 & 8 & $\begin{array}{l}\text { SSA1 } \\
\text { SSP5 }\end{array}$ & 54 & ASPKR19 & 54 & ANSPK2 & 54 & SSPK2 \\
\hline 9 & ASPKR2 & 9 & ANSM2 & 9 & $\begin{array}{l}\text { SSPKR } 3 \\
\text { SSP }\end{array}$ & 55 & ASP15 & 55 & ANSPRL1 & 55 & SSPRL1 \\
\hline 10 & ASPKR3 & 10 & ANSM3 & 10 & SSPKR4 & 56 & ASPKR20 & 56 & ANSP16 & 56 & SSPKR19 \\
\hline 11 & ASM1 & 11 & ANSM4 & 11 & SSP6 & 57 & ASP16 & 57 & ANSPB1 & 57 & SSB6 \\
\hline 12 & ASK2 & 12 & ANSP2 & 12 & SSPKR5 & 58 & ASK10 & 58 & ANSPK3 & 58 & SSPB2 \\
\hline 13 & ASM2 & 13 & ANSPKR1 & 13 & SSPKR6 & 59 & ASPK1 & 59 & ANSP17 & 59 & SSPKR20 \\
\hline 14 & ASPKR4 & 14 & ANSK4 & 14 & SSPKR7 & 60 & ASP17 & 60 & ANSPKR13 & 60 & SSPB3 \\
\hline 15 & ASPKR5 & 15 & ANSPKR 2 & 15 & SSP7 & 61 & ASP18 & 61 & ANSPKR14 & 61 & SSPKR21 \\
\hline 16 & ASP4 & 16 & ANSPKR3 & 16 & SSP8 & 62 & ASPKRL1 & 62 & ANSPKR15 & 62 & SSPKR22 \\
\hline 17 & ASPKR6 & 17 & ANSP3 & 17 & $\begin{array}{l}\text { SNFO } \\
\text { SSB1 }\end{array}$ & 63 & ASP19 & 63 & ANSPB2 & 63 & SSB7 \\
\hline 18 & ASPKR7 & 18 & ANSPKR4 & 18 & SSPKR8 & 64 & ASPK2 & 64 & ANSPKR16 & 64 & SSPKR23 \\
\hline 19 & ASPKR8 & 19 & ANSK5 & 19 & SSM1 & 65 & ASP20 & 65 & ANSPKR17 & 65 & SSPKR24 \\
\hline 20 & ASP5 & 20 & ANSPKR5 & 20 & SSM2 & 66 & ASKP1 & 66 & ANSPKR18 & 66 & SSPB4 \\
\hline 21 & ASP6 & 21 & ANSP4 & 21 & SSPKR9 & 67 & ASP21 & 67 & ANSPB3 & 67 & SSPKR25 \\
\hline 22 & ASPKR9 & 22 & ANSPKR6 & 22 & SSK2 & 68 & ASPRL1 & 68 & ANSPKR19 & 68 & SSB8 \\
\hline 23 & ASP7 & 23 & ANSK6 & 23 & SSP9 & 69 & ASPB1 & & & & \\
\hline 24 & ASK3 & 24 & ANSB4 & 24 & SSPK & 70 & ASPKR21 & & & & \\
\hline 25 & ASP8 & 25 & ANSB5 & 25 & SSPKR 11 & 71 & ASPKR22 & & & & \\
\hline 26 & ASPKR10 & 26 & ANSP5 & 26 & $\begin{array}{l}\text { SSPKK } \\
\text { SSB? }\end{array}$ & 72 & ASPKR23 & & & & \\
\hline 27 & ASP9 & 27 & ANSP6 & 27 & SSB 3 & 73 & ASPKR24 & & & & \\
\hline 28 & ASP10 & 28 & ANSB6 & 28 & SSB4 & 74 & ASPK3 & & & & \\
\hline 29 & ASP11 & 29 & ANSK7 & 29 & $\begin{array}{l}\text { SSB4 } \\
\text { SSPKL }\end{array}$ & 75 & ASPKR25 & & & & \\
\hline 30 & ASK4 & 30 & ANSPKR7 & 30 & SSPKRIL & 76 & ASB9 & & & & \\
\hline 31 & ASPKR11 & 31 & ANSP7 & 31 & $\begin{array}{l}\text { SSPKK } 13 \\
\text { SCDKD } 14\end{array}$ & 77 & ASPKR26 & & & & \\
\hline 32 & ASPKR12 & 32 & ANSPKR8 & 32 & SSPRK14 & 78 & ASPB2 & & & & \\
\hline 33 & ASP12 & 33 & ANSP8 & $\begin{array}{l}32 \\
33\end{array}$ & SSPIV & 79 & ASPKR27 & & & & \\
\hline 34 & ASK5 & 34 & ANSPKR9 & $\begin{array}{l}33 \\
34\end{array}$ & $\begin{array}{l}\text { SSPK1 } \\
\text { CCD11 }\end{array}$ & 80 & ASP22 & & & & \\
\hline 35 & ASPKR13 & 35 & $\begin{array}{l}\text { ANSP9 } \\
\text { ANS }\end{array}$ & $\begin{array}{l}34 \\
35\end{array}$ & $\begin{array}{l}\text { SSPII } \\
\text { SCDED }\end{array}$ & 81 & ASB1 & & & & \\
\hline 36 & ASK6 & 36 & ANSK8 8 & $\begin{array}{l}35 \\
36\end{array}$ & SSPKRIS & 82 & ASB11 & & & & \\
\hline 37 & ASM3 & 37 & ANSK9 & $\begin{array}{l}36 \\
37\end{array}$ & $\begin{array}{l}\text { SSK } 3 \\
\text { CCD12 }\end{array}$ & 83 & ASBK1 & & & & \\
\hline 38 & ASK7 & 38 & ANSM5 & $\begin{array}{l}31 \\
38\end{array}$ & $\begin{array}{l}\text { SSPIL } \\
\text { SSB5 }\end{array}$ & 84 & ASPKR28 & & & & \\
\hline
\end{tabular}

Table 2. The characteristics of bacterial isolates from the extract suspensions of oil palm empty fruti bunches in the aerobic, anaerobic, and facultative anaerobic conditions

\footnotetext{
Fermentation

Condition*) Characteristics*)

Aerobic (84) Round White (17), Irregular White (6), Round Clear (10), Irregular Clear (1), Round Yellow (10), Round Red (3), Round Turbid White (14), No Turbid White Regular (15), Round Solid Yellow (1), Round Yellowish White (3), Round Clear White (2), Irregular Yellowish Clear (1), Round Orange (1)

Anaerobic $\quad$ Round White (13), Irregular White (5), Round Clear (6), Irregular Clear (3), Round Yellow (8), Irregular Yellow (68) (1), Round Red (5), Round Turbid White (11), Irregular Turbidity White (9), Round Solid Yellow (1), Round Yellowish White (2), Irregular Yellowish White (1), Round Clear White (2), Irregular Clear White (1)

Facultative $\quad$ Round White (19), Irregular White (2), Round Turbid White (8), Irregular White Turbid (19), Round Yellow (4), Anaerobic (68) Round Clear (7), Irregular Clear (2), Round Red ( 2), Round Yellowish White (2), Round Clear White (2), Irregular Clear White (1) 

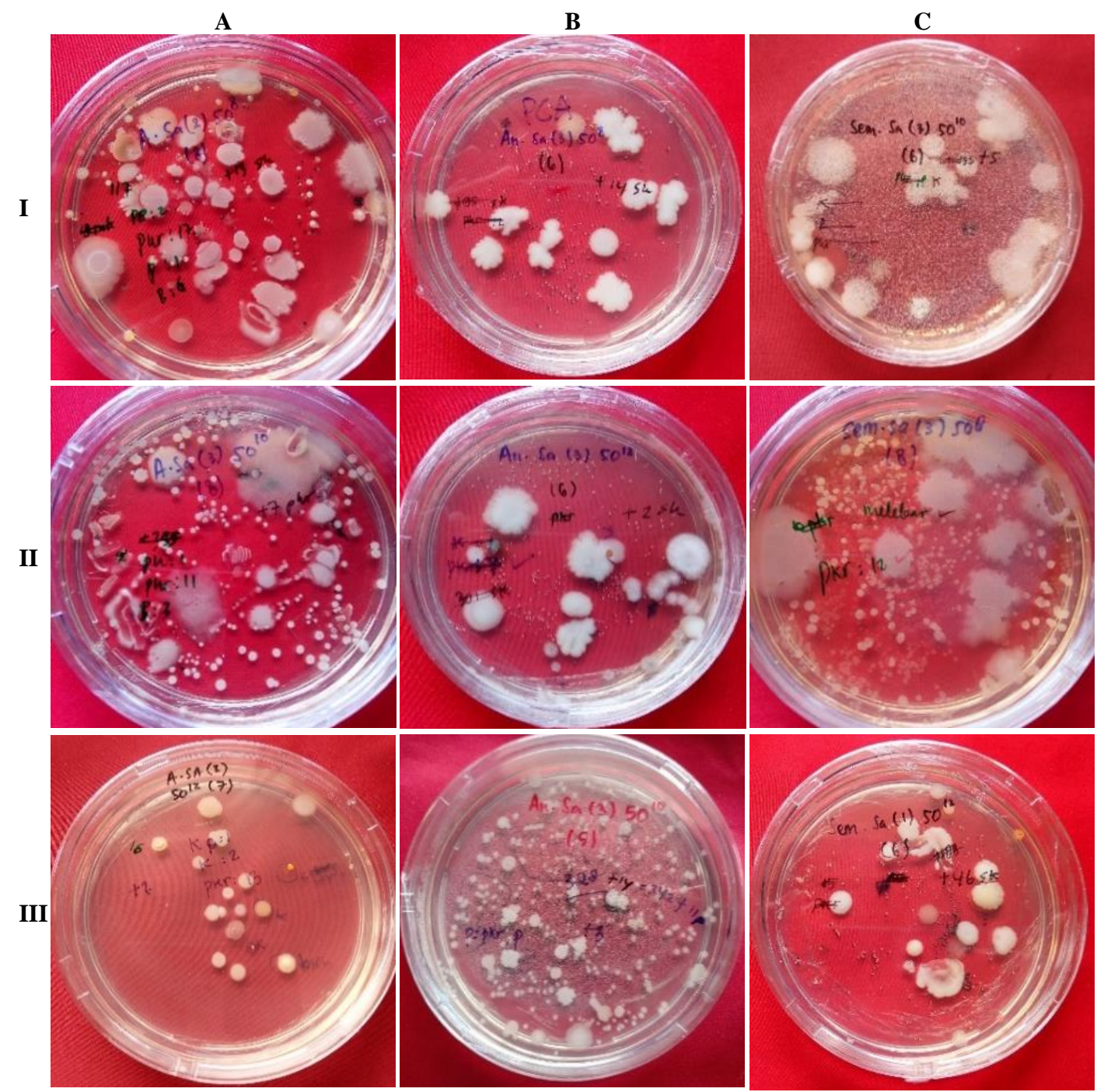

Figure 2. Examples of the abundance of bacteria isolate from the extract suspension of EFB in aerobe, anaerobe, and facultative anaerobe

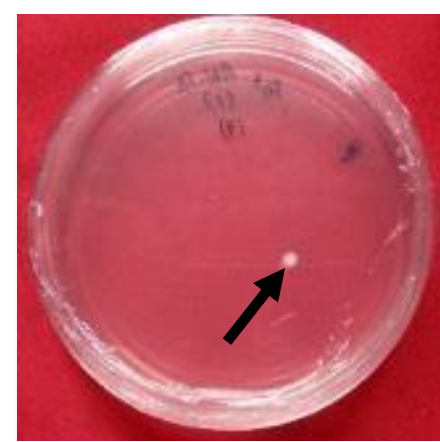

$\mathbf{A}$

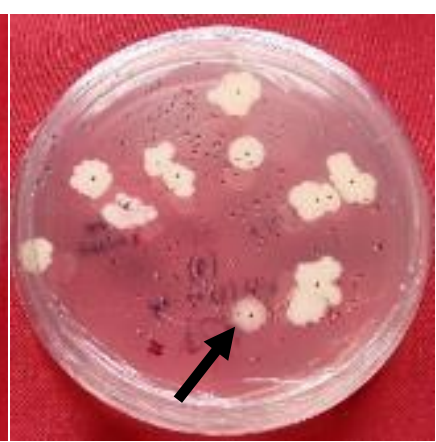

B

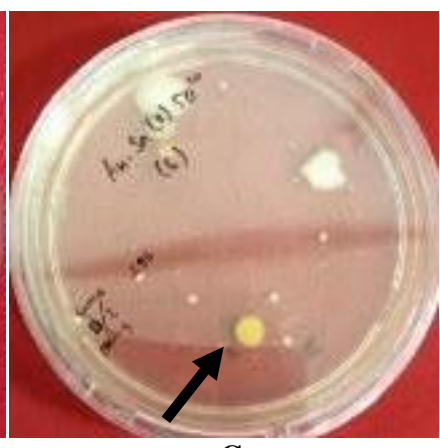

C

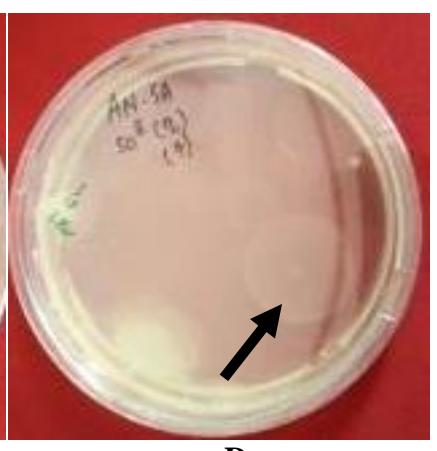

D

Figure 3. The characteristics of bacterial isolates from the extract suspensions of oil palm empty fruit bunches: A. Bacterial isolates with yellow color and round shape, B. Bacterial isolates with turbid white color and irregular shape, C. Bacterial isolates with yellow color and round shape, D. Clear bacterial isolates and round shape

In the three fermentation conditions which were aerobic, anaerobic, and facultative anaerobic, dominating bacteria in the extract solutions of oil palm empty fruit bunches were 168 gram-positive bacterial isolates
(76.36\%), while gram-negative bacteria were 52 bacterial isolates (23.64\%) (Figure 4.A). Gram-positive bacterial isolates were $27.26 \%$ in the aerobic condition, $24.55 \%$ in the anaerobic condition, and $24.55 \%$ in the facultative 
anaerobic condition. On the other hand, gram-negative bacterial isolates were $10.92 \%$ in the aerobic condition, $6.36 \%$ in the anaerobic condition, and $6.36 \%$ in the facultative anaerobic condition. Gram-positive bacterial isolates were higher than gram-negative bacterial isolates. These results are in line with Lai et al. (2017) who also reported that the results of isolation of oil palm empty fruit bunches compost were dominated by gram-positive bacteria ( 8 bacterial isolates) followed by gram-negative bacteria ( 2 bacterial isolates). According to Mistou et al. (2016), gram-positive bacteria have cell walls that contain thick peptidoglycan while gram-negative bacteria have thin peptidoglycan content. Thin peptidoglycan content makes bacterial cells easily broken and destroyed when reacting with $\mathrm{KOH}$ (Chandra and Mani 2011). Gram-negative bacteria have an outer membrane that contains lipopolysaccharide compounds, where these compounds play a role in influencing plant metabolic processes and damaging cell membranes, thus potentially as plant pathogens (Zhang et al. 2013).

The results of oxidation-fermentation tests indicated that the bacterial isolates were more fermentative compared to oxidative. Total 197 isolates $(89.55 \%)$ were bacteria fermentative and oxidative bacteria were 23 isolates $(10.45 \%)$ (Figure 4.B). Bacteria fermentative isolates were $34.55 \%$ in the aerobic condition, $26.36 \%$ in the anaerobic condition, and $28.64 \%$ in the facultative anaerobic condition. On the other hand, the oxidative bacteria isolates were $3.64 \%$ in the aerobic condition, $4.54 \%$ in the anaerobic condition, and $2.27 \%$ in the facultative anaerobic condition. According to Hadi et al. (2019), the oxidative bacteria included the aerobic bacteria, and the fermentative bacteria included the facultative anaerobic bacteria.

In the soft rot test, the bacterial isolates obtained showed a negative reaction (did not cause soft rot) more than a positive reaction (causing soft rot) (Figure 4.C). Soft rot negative was as many as 158 isolates $(71.82 \%)$ while soft rot positive was 62 isolates $(28.18 \%)$. Bacterial isolates that showed soft rot positive reactions were $9.09 \%$ in the aerobic condition, $10.45 \%$ in the anaerobic condition, and $8.64 \%$ in the facultative anaerobic condition. On the other hand, bacterial isolates that showed negative soft rot reactions were $29.09 \%$ in the aerobic condition, $20.46 \%$ in the anaerobic condition, and $22.27 \%$ in the facultative anaerobic condition. According to Lee et al. (2014), bacteria that show positive reactions suspected as a pathogen because the bacteria produce the enzyme pectinase that can break down pectin and cellulose of the plant cell walls so that tuber system will be decomposed. Pectinolytic enzymes break down pectin which is an intercell adhesive in plant tissue. Factors affecting the development of soft rot in potato tubers are conditions (high temperature and humidity, low oxygen concentration, wound of host protective tissue) (Krejzar et al. 2008). Himel et al. (2016), Dickeya sp. and Erwinia carotovora are examples of pathogens that cause soft rot in fruits. From this statement, it is necessary to conduct a pathogenicity test in the form of the hypersensitive and hypovirulent test.

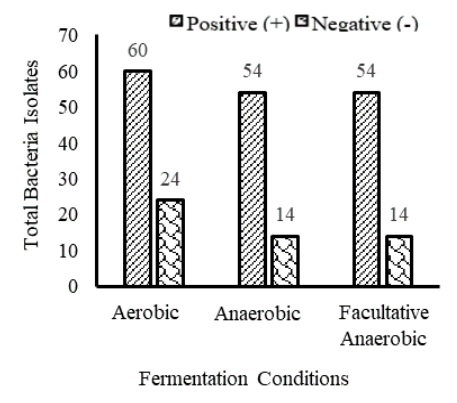

A

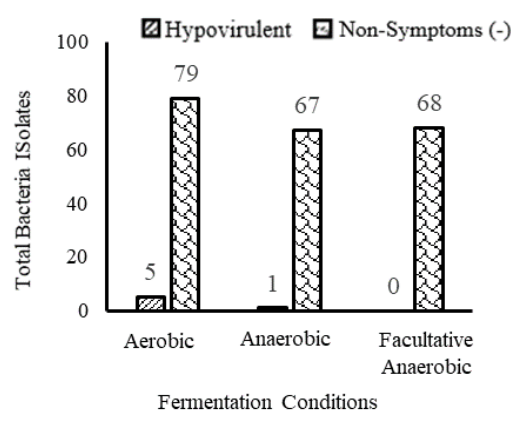

D

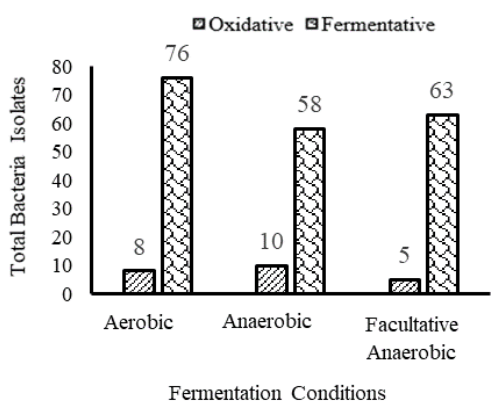

B

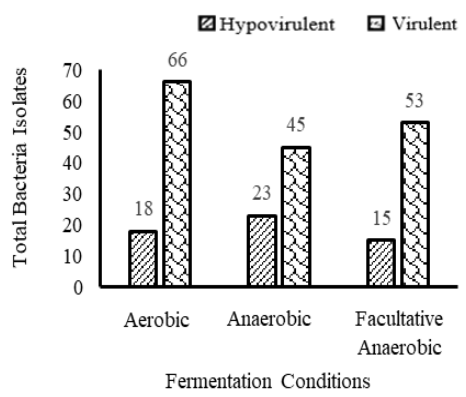

$\mathbf{E}$

Figure 4. Bacterial characteristic based on the test results: A. Gram Test, B. OF Test, C. Soft rot Test, D. Hypersensitivity Test, E. Hypovirulent Test 
In the hypersensitive test, many bacterial isolates that react negatively were more compared to the bacterial isolates that react positively (cause symptoms necrosis). According to Balint-Kurti (2019), positive reactions occur due to cells that are physically penetration or direct contact with the pathogen so that the cells will die in the infection site. Thus, it was suspected that the bacterial isolates obtained were not dominated by pathogens because of the positive reaction bacteria were only 6 isolates $(2.73 \%)$ out of 220 bacterial isolates obtained (Figure 4.D). Bacterial isolates that showed hypersensitive symptoms were $2.27 \%$ in the aerobic condition and $0.46 \%$ in the anaerobic condition. On the other hand, bacterial isolates that showed non-hypersensitive symptoms were $35.91 \%$ in the aerobic condition, $30.45 \%$ in the anaerobic condition, and $30.91 \%$ in the facultative anaerobic condition.

Furthermore, the experimental results showed that the characteristic of bacterial isolates from the extract suspension of oil palm empty fruit bunches was more virulent compared to hypovirulent. Virulent bacteria were 164 isolates $(74.55 \%)$ and hypovirulent were 56 isolates $(25.45 \%)$ (Figure 4.E). Bacterial isolates that showed virulently were $30 \%$ in the aerobic condition, $20.46 \%$ in the anaerobic condition, and $24.09 \%$ in the facultative anaerobic condition. On the other hand, bacterial isolates that show hypovirulent were $8.18 \%$ in the aerobic condition, $10.45 \%$ in the anaerobic condition, and $6.82 \%$ in the facultative anaerobic condition. According to Sharma et al. (2018), hypovirulent is associated with a decreased ability of microbes in causing illness, so it cannot produce severe disease and can be used as a biocontrol agent.

Based on the results of this study, the extract suspension of oil palm empty fruit bunches the aerobic, anaerobic, and facultative anaerobic conditions produces various characteristics of bacterial isolates. Different bacterial characteristics indicate that each bacterial isolate came from different types so that the characteristics test can be used as a basis for identification of bacteria (Babu et al. 2017).

In conclusion, the bacterial abundance from the extract suspension of oil palm empty fruit bunches at the aerobic conditions was higher than the anaerobic conditions, and the anaerobic conditions were higher than the facultative anaerobic conditions. Moreover, the characteristics of most bacterial isolates from the extract suspension of oil palm empty fruit bunches were white color, round shape, including a gram-positive bacteria, fermentative, soft rot negative, did not cause necrosis of tobacco leaves, and virulent.

\section{ACKNOWLEDGEMENTS}

We are very grateful to the University of Lampung (Unila) Bandar Lampung, Indonesia for "Hibah Profesor" from UNILA BLU's research grant. We also thank the Research and Community Service Institution and the Faculty of Agriculture of the University of Lampung which have facilitated the research and to PTPN VII, Rejosari,
Natar, Lampung Province which has provided oil palm empty fruit bunches as research materials. We also would like to thank Dr. Kuswanta Futas Hidayat for his valuable comments.

\section{REFERENCES}

Adrizal, Heryandi Y, Amizar R, Mahata ME. 2017. Evaluation of pineapple (Ananas comosus [L.] Merr) waste fermented using different local microorganisms solutions as poultry feeds. Pak J Nutr 16 (2): 84-89.

Ariana P, Krishna, Candra. 2017. Isolation and characterization of lignocellulolytic microbes from oil palm empty fruit bunches (EFB). J Environ Sustain 1 (1): 1-9.

Astriani M, Mukharomah E. 2017. The use of inquiry strategies in learning the isolation of bacteria from local microorganisms solution and its application as a biological fertilizer. Florea J 4 (1): 17-23. [Indonesian]

Babu SV, Triveni S, Reddy RS, Sathyanarayana J. 2017. Screening of maize rhizospheric phosphate solubilizing isolates for plant growthpromoting characteristics. Intl J Curr Microbiol Appl Sci 6: 20902101.

Balint-Kurti P. 2019. The plant hypersensitive response: concepts, control and consequences. Mol Plant Pathol 20 (8): 1163-1178. DOI: 10.1111/mpp. 12821 .

Chandra TJ, Mani PS. 2011. A study of 2 rapid tests to differentiate grampositive and gram-negative aerobic bacteria. J Med Allied Sci 1 (2): 84-85.

Chin CFS, Furuya Y, Huzairi M, Zainudin M, Ramli N, Hassan MA, Tashiro Y, Sakai K. 2017. Novel multifunctional plant growthpromoting bacteria in the co-composting of waste palm oil industrial waste. J Biosci Bioeng 124 (5): 506-513. DOI: 10.1016/j.jbiosc.2017.05.016.

Cymru GIG, Wales NHS. 2010. Oxidation/fermentation of glucose test. Standards Unit, Department for Evaluations, Standards and Training 2: $1-10$.

Dermiyati, Suharjo R, Telaumbanua M, Ilmiasari Y, Yosita R, Annisa RM, Sari AW, Andayani AP, Yulianti DM. 2019. Population of phosphate solubilizing bacteria in the liquid organic fertilizer created from palm oil bunches and pineapple rhizome. Biodiversitas 20 (11): 3315-3321. DOI: 10.13057/biodiv/d201126.

Hadi SN, Dewi PS, Kartini. 2019. Identification of the ultisol indigenous bacteria from Banyumas Regency is based on the characteristics of morphology, physiology, and biochemistry. Int Conf Sustain Agric Rural Dev. IOP Conf Ser: Earth Environ Sci 250: 012095. DOI: 10.1088/1755-1315/250/1/012095.

Han J, Kim J. 2018. Process simulation and optimization of EFB's 10-MW power plant. Comput Aided Chem Eng 43: 723-729.

Harith ZT, Ibrahim NA, Yusoff N. 2014. Isolation and identification of locally isolated lignin-degrading bacteria. J Sustain Sci Manag 9 (2): 114-118.

Himel RM, Ali ME, Khan AA, Akanda AM, Karim M. 2016. Characterization and identification of soft rot bacterial pathogens of different fruits in Bangladesh. Intl $\mathrm{J}$ Biosci 9 (1): 1-9. DOI: 10.12692/ijb/9.1.1-9.

Hoe TK, Sarmidi MR, Alwee SSRS, Zakaria ZA. 2016. Recycling of empty palm oil fruit bunch as a potential carrier for biofertilizer formulation. J Technol (Sci Eng) 78 (2): 165-170. DOI: 10.11113/jt.v78.7375

Istiqomah, Kusumawati DE. 2018. The utilization of Bacillus subtilis and Pseudomonas fluorescens in the biological control of Ralstonia solanacearum that causes bacterial wilting on tomatoes. J Agro 5 (1): 1-12. DOI: 10.15575/2305. [Indonesian]

Khlaif HM, Wreikat BI. 2018. The relationship of potato bacterial soft rot disease with reduced sugar content of potato tubers and calcium. Jordan J Agric Sci 14 (1): 81-90.

Krejzar V, Mertelik J, Pankova I, Kloudova K, Kudela V. 2008. Pseudomonas marginalis Associated with Soft Rot of Zantedeschia spp. Plant Protect Sci 44 (3): 85-90.

Lai CMT, Chua HB, Danquah MK, Saptor A. 2017. Isolation of thermophilic lignin-degrading bacteria from oil-palm empty fruit bunch (FEB) compost. 29th Symposium of Malaysian Chemical 
Engineers (SOMChE) 2016. IOP Conf Ser: Mater Sci Eng 206 (2017): 012016. DOI: 10.1088/1757-899X/206/1/012016.

Lee DH, Kim JB, Lim JA, Han SW, Heu S. 2014. Genetic diversity of Pectobacterium carotovorum subps. Basiliensis isolated in Korea. Plant Pathol J 30 (2): 117-124. DOI: 10.5423/ppj.oa.12.2013.0117.

Linda TM, Siregar S, Fitri WD, Martina A, Lestari W, Roslim DI, Hapsoh. 2018. Isolation and screening of culturable endophytic bacteria from leaf of rubber plant that produces chitinase. SEMIRATA-International Conference on Science and Technology 2018. IOP Conf Ser J Phys: Conf Ser 1116 (2018). DOI 10.1088/1742-6596/1116/5/052038.

Mariska D. 2019. Indonesia sees an increase in palm oil production, exports. Jakarta Globe. https://jakartaglobe.id/business/indonesiasees-increase-in-palm-oil-production-exports.

Md Yunos NSH, Baharuddin AS, Md Yunos KF, Hafid HS, Busu Z Mokhtar MN, Sulaiman A, Md Som A. 2015. The physicochemical characteristics of residual oil and fibers from palm oil empty fruit bunches. BioRes 10 (1): 14-29.

Mistou MY, Sutcliffe IC, Van Sorge NM. 2016. Bacterial glycobiology: rhamnose-containing cell wall polysaccharides in gram-positive bacteria. FEMS Microbiol Rev 40 (4): 464-479. DOI: 10.1093/femsre/fuw006.

Rahayu DE, Wirjodirdjo B, Hadi W. 2019. Availability of empty fruit bunch as biomass feedstock for sustainability of bioenergy product (system dynamic approach). The 2nd International Conference on Science, Mathematics, Environment, and Education. AIP Conf Proc 2194 (2019): 020095. DOI: 10.1063/1.5139827.

Rosli NS, Harun S, Jahim JMd, Othaman R. 2017. Chemical and physical characterization of palm oil empty fruit bunch. Malays $\mathrm{J}$ Anal Sci 21 (1): 188-196. DOI: 10.17576/mjas-2017-2101-22.

Santi LP, Kalbuadi DN, Goenadi DH. 2019. Empty fruit bunches as a potential source for biosilica fertilizer for palm oil. J Trop Biodivers Biotechnol 4: 90-96.

Sharma M, Guleria S, Singh K, Chauhan A, Kulshrestha S. 2018. Mycovirus associated hypovirulence, a potential method for biological control of Fusarium species. Virus Dis 29 (2): 134-140. DOI: $10.1007 / \mathrm{s} 13337-018-0438-4$.

Suharjo R, Aeny TN, Hasanudin U, Sukmaratri TE, Kisno R, Khoironi T, Safitri DA. 2018. Potential of endophytic bacteria as plant growth promoters and antagonists against pineapple-fungal plant pathogens in Indonesia. Proceedings of the International Symposium on Innovative Crop Protection for Sustainable Agriculture. Lampung University, Bandar Lampung, Indonesia, March 7-8, 2018.

Tahir AA, Barnoh NFM, Yusof N, Said NNM, Utsumi M, Yen AM, Hashim H, Noor MJMM, Akhir FNMD, Mohammad SE, Sugiura N, Othman N, Zakaria Z, Hara H. 2019. Microbial diversity in decaying palm oil empty fruit bunches (EFB) and isolation of lignin-degrading bacteria from tropical environments. Microb Environ 34 (2): 161-168. DOI: $10.1264 /$ jsme2.ME18117.

Telaumbanua M, Dermiyati, Suharjo R. 2019. Design a stirrer and aerator systems for automatic MOL production from palm oil and pineapple waste using aerobics, semi aerobic, and anaerobic methods. Journal of Agricultural Engineering Lampung 8 (4): 11-17. DOI: 10.23960/jtep-1.v8.i4.234-242. [Indonesian]

Tortora GJ. 2019. Microbiology: An Introduction. Pearson, New York.

USDA. 2019. Indonesia Oilseeds and Products Annual 2019. GAIN Report Number: ID: 1903. Date: 3/15/2019. https://apps.fas.usda.gov/newgainapi/api/report/downloadreportbyfile name?filename $=$ Oilseeds $\% 20$ and $\% 20$ Products $\% 20$ Annual_Jakarta_I ndonesia_3-15-2019.pdf.

Yi LG, Siti Aishah Abd Wahid SAA, Tamilarasan P, Siang CS. 2019. Enhancing sustainable oil palm cultivation using compost. J Oil Palm Res 31 (3): 412-421. DOI: 10.21894/Jopr.2019.0037.

Zainudin MHM, Hassan MA, Tokura M, Shirai Y. 2013. Indigenous cellulolytic and hemicellulolytic bacteria enhanced rapid cocomposting of lignocellulose oil palm empty fruit bunch with palm oil mill effluent anaerobic sludge. Bioresour Technol 147: 632-635.

Zhang G, Meledith TC, Kahne D. 2013. In the essentiality of lipopolysaccharide to gram-negative bacteria. Curr Opin Microbiol 16: 779-785. DOI: 10.1016/j.mib.2013.09.007. 